On Names in South Asia: Iteration, (Im)propriety and Dissimulation

\title{
Secularism's Names: Commitment to Confusion and the Pedagogy of the Name
}

Jacob Copeman

\section{(2) OpenEdition}

\section{Journals}

Electronic version

URL: http://journals.openedition.org/samaj/4012

DOI: $10.4000 /$ samaj.4012

ISSN: $1960-6060$

Publisher

Association pour la recherche sur l'Asie du Sud (ARAS)

Electronic reference

Jacob Copeman, "Secularism's Names: Commitment to Confusion and the Pedagogy of the Name », South Asia Multidisciplinary Academic Journal [Online], 12 | 2015, Online since 15 October 2015 connection on 03 May 2019. URL : http://journals.openedition.org/samaj/4012 ; DOI : 10.4000/ samaj.4012

This text was automatically generated on 3 May 2019.

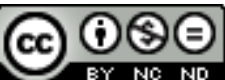

This work is licensed under a Creative Commons Attribution-NonCommercial-NoDerivatives 4.0 International License. 


\title{
Secularism's Names: Commitment to Confusion and the Pedagogy of the Name
}

\author{
Jacob Copeman
}

\section{AUTHOR'S NOTE}

I am grateful to the contributors to this special issue, especially Veena Das, as well as audiences in London, Göttingen and Madison for valuable suggestions. I owe much to Nathaniel Roberts, Dwaipayan Banerjee, Diego Malara, Matjaz Vidmar, Aya Ikegame, Arkotong Longkumer and the anonymous journal reviewers for their comments and suggestions on earlier drafts of this article, and to Prasannanshu, Johannes Quack, Patricia Jeffery, Hugo Gorringe, Hannah Lesshafft and Neeti Nair for fruitful conversations. Research and writing for this special issue was made possible by an Independent Social Research Foundation Early Career Fellowship.

We have been clueless over the fact that why did SRK [Bollywood superstar Shahrukh Khan] choose to write his son AbRam's name in such a different manner and here's what the actor has explained.

'His name is based on a variation of Prophet Abraham. And I liked the connotation that it's...a secular name. We are a Hindu-Muslim family... and

I want my children to grow up without any difference of opinion in the name. It's nice this way and has more universal appeal' [...] Shahrukh Khan already has two kids with wife Gauri Khan. His son named Aryan Khan is 15 years old, while his daughter Suhana is 12 years old. (Filmibeat, 21 August 2013) 


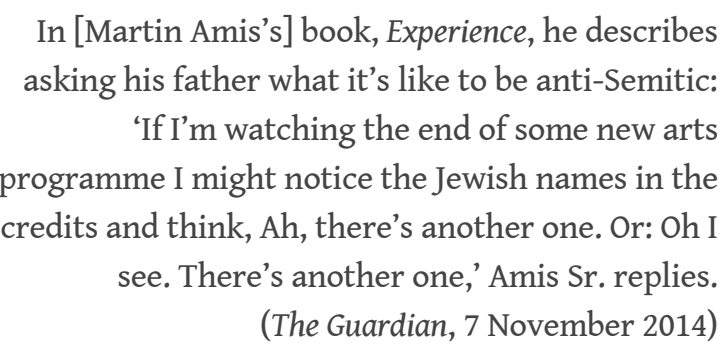

\section{Introduction: anti-algorithm}

It is a truism that a person's name is liable to convey a good deal of information about them. Conventional rules tied to the names 'Gurpreet' and 'Muhammad' ensure that when someone sees or hears those names, they will probably assume that they designate individuals from, respectively, Sikh and Muslim backgrounds. Personal names, indeed, come with considerable demographic baggage (Alter 2013:13), frequently acting as key vehicles for the automatic categorization of their bearers and the noticing of the category before the person (as seen in the quote from the Guardian newspaper in one of the epigraphs above).

This is as true in South Asia as it is elsewhere where the two (or more) names of an individual are expected to reflect without ambiguity, the gender, caste and religion of that individual' (Banerjee 2008: xiv). The assumption of a correlation between personal name and caste and/or religion has led to a variety of attempts to harness the information conveyed in South Asian names for governmental and biopolitical ends that for some will contain echoes of the colonial project of 'control by classification' (Ingold 2011: 174). Consider the development by UK epidemiologists of name-recognition algorithms to identify not only British South Asians but the regional, linguistic and ethnic subgroups within this larger category-the stated purpose being to supplement existing datasets used in research on ethnic variations in health with more accurate information on subjects' ethnicity (Cummins et al. 1999, Nanchahal et al. 2001). Most recently, political anthropologist Raphael Susewind (2014) has explored the potential of an open-source algorithm's use of local name registers in Uttar Pradesh to provide 'probabilistic inference of religious community.' The explicit aim is to provide insights into, and ameliorative policies in respect of, group-based inequality. Since (again) adequate datasets on religious communities do not exist, the algorithm is seen to 'provide [...] a workaround by probabilistically exploiting the communal connotations of names; it transforms name lists-which are readily available-into a new source of demographic data' (Susewind 2014: 1).

3 It is important to be clear that the algorithms referred to are not, and could never be, $100 \%$ accurate, and to be fair no one is proposing they ever could be. As Susewind (2014:3) is careful to point out, names do not ineludibly reflect religious background or ethnicity (see also Stewart 2000: 51). Quite apart from boundary-crossing names such as those used by the north Indian Meo community (e.g. Ram Khan, Shankar Khan), which are irreducible to the religious either/or that such algorithms demand (not unlike the colonial state's requirement of binary legibility), surname-titles such as 'Chaudhary' may belong to a Hindu, Muslim or another community besides, and a variety of 'neutral' obfuscators exist, such as Kumar and Singh, that usually are not caste-specific, ${ }^{1}$ while a 
caste surname that strongly signifies a particular community in one region of the country is liable to signify a different one elsewhere (e.g. Nayak).

4 Nevertheless, and putting to one side for the moment ethical questions raised by such endeavours, the logic informing the algorithms remains powerful-personal names usually do provide telling insights into the community backgrounds of their bearers, and answers to the everyday question 'What is your name?' are perpetually fed into a kind of social algorithm for the calculation of identity, in a corridor, on a train, in a store, on the phone, or wherever. But what if South Asian names ceased to be capable of providing such 'data'-and in fact served to scramble any attempt at automatic categorization? It is that question that this essay explores. There are of course numerous ways in which persons convey demographic baggage other than through their names-'some information is always evident in face-to-face interaction, because we are all ambulatory autobiographies continuously and unavoidably emitting data for others' senses and machines' (Marx 1999: 101) -but as Goffman (1963: 76) pointed out, of all the markers of identity personal names are perhaps 'the easiest to tamper with.'

5 The essay is grounded in on-going ethnographic work amongst committed proponents of secularism in India, namely rationalist, humanist, and atheist organisations and their members, ${ }^{2}$ but it also explores allied attempts to 'secularise' names made by people and institutions that would not identify as rationalist but certainly would describe themselves as secular. What I call 'secular names' are, by and large, names that have been 'tampered with' through acts of renaming to downplay or extinguish demographic (i.e. caste and religious) markers that at the same time are also, of course, markers of belonging. Renaming, here, may refer to an activist's self-renaming, or to the naming of his or her child in ways that do not accord with convention. M.N. Srinivas's (2012: 335-6) use of the term 'secular names' is similar but different to mine. He employed it to refer to a move amongst Karnataka's urban elites away from naming children after deities. Yet among the examples he gives are Ashok, Sanjay and Ravi, names which, because of their Sanskrit origin, continue to encode their bearers' Hindu backgrounds, regardless of their not being the names of Hindu gods. In some cases, amongst secular activists, this is where their attempts to employ a secular name end. However, I include in my definition of secular naming practices more radical and diverse attempts to onomastically cloak a person's religious and/or caste background, as we shall see.

6 Some secular names carry an explicitly pedagogical message, part of their purpose being to encourage reflection upon their own nature and, via that, a person on their worldview. Names that withhold the information usually associated with them, in calling attention to themselves, may provoke reflection on the arbitrariness, changeability, and role of names in forming the very community distinctions they signify. That is not to say they always succeed in this, but rather to suggest that this is where some users of such names locate the value in them. I shall thus employ the term 'meta-name' to call attention to the pedagogy of the name in certain instances of secular onomastic experimentation.

7 I identify two main strategies used by activists for the production of 'secular names': purification of the caste and religious connotations of names, and multiplication of those connotations in the giving of boundary-crossing names. At certain points the strategies overlap; but I see heuristic value in retaining the distinction for the time being. Common to each is a rationale that seeks to break the association between name and pigeonholed identity, an association that it is important to recognise is itself the product of diverse procedures by which group boundaries were solidified both by their interactions with the 
state and with various kinds of reform movements, caste associations, and other mechanisms for removing any ambiguity with regard to the straightforward identification of name with the social group (see Das \& Copeman this issue, Steinberg this issue). We might say that if prior deeds of purification operated according to a logic of either/or, the two strategies pursued by activists operate according to logics of, one the one hand, both/and (boundary-crossing names), and on the other, neither/nor (purified names). The two strategies demonstrate the extent to which naming has become subject to experimentation amongst rationalists and secular activists. Though I do not claim that all or even a majority of activists engage in such onomastic experimentation, every rationalist is able to point to examples from within their circle of activism, and there are rationalist associations where naming innovations are absolutely normal and indeed required. For Punjab's dynamic and influential Tarksheel organisation, for instance, dropping one's caste surname is a condition of membership.

Before turning to the specific strategies employed, it is important first to be clear about why they are experimenting thus. I suggest there are three principal reasons. First, they take up a position that sees the inescapable associations and automatic categorization of personal names as leading directly to the circumscription of human possibility. For Bourdieu (1991: 121), names 'inaugurate the actor's identity and inform him in an authoritative manner of what he is and what he must be,' and this can equally describe the rationalists' view. Rationalist activists seek to circumvent the ought self imposed on a person by their name; to liberate themselves and others from its shackles. Second, there is the matter of demonstrating consistency. Anti-caste activism is folded into the Indian rationalist worldview. Famous for their anti-superstition and miracle demonstration campaigns, activists frequently describe caste as the biggest superstition of all. Retention of a caste surname leaves activists open to charges of hypocrisy, similar to the recent accusations levelled at Arundhati Roy who, after the publication of her new introduction to B.R. Ambedkar's The Annihilation of Caste, was challenged on her continued use of a caste surname.

9 Third, and most important, is activists' acute recognition of the role of names in facilitating multiple forms of discrimination. The by now classic study by economists Bertrand and Mullainathan (2004), which revealed the dramatic extent to which employers in Boston and Chicago discriminate against equally qualified candidates based solely on whether their names are typically 'white' or 'black,' was recently replicated for a variety of Indian metropolitan contexts to revealing effect. Thorat and Attewell's (2010) study entailed responding to private sector job adverts with CVs demonstrating equal qualifications, but with names indicative of a number of different caste and religious backgrounds. While the finding that applicants with discernibly Dalit, low caste or Muslim-sounding names were far less likely than those with high caste ones to hear back from employers will probably surprise few social scientists, the research is valuable for vividly crystallising the socio-economic stakes of personal names in the region, and for providing a compelling counter to illusory rhetoric that celebrates the supposed 'postcaste' egalitarianism of the liberalised economy. The demographic baggage of names, then, plays a key role in everyday discrimination, from the notorious difficulties faced by people with low-caste or Islamic names in finding properties for rent, to obtaining jobs, and so on.

10 Activists' onomastic experiments are thus addressed to a specific set of problems. In his reflections on Dewey and Foucault's differing approaches to problems as a topic of 
enquiry, Rabinow (2006: 42-3) notes that the former's emphasis is on identification and rectification of problems, while the latter's 'problematisation' is oriented towards understanding how different responses to a problem are 'simultaneously possible.' Elements of both perspectives inhere in activists' strategies and in my account of them. With Dewey, activists seek to 'clarify and realign a problematic situation' (Rabinow 2006: 42). With Foucault I seek to understand the problematic dissonances between the different attempts made to realign the problem, and how addressing the problem can create a set of new ones. Thus, while the first part of the paper identifies the differing onomastic strategies employed by activists to attend to the problem of names and automatic categorization, the latter sections show how the proffered solutions constitute themselves another field of problems. Acts of renaming, and non-normative names as such, can be and are contested. Performative utterances, if they are not enacted in ordinary circumstances but, for instance, on the stage, out of earshot, or in a language the hearer does not understand, will be simply 'hollow or void' (Austin 1962: 22), and secular naming practices by their very nature are extraordinary-this is how they gain their power but it also leaves them open to being ignored, ridiculed or classed as illegitimate, especially by those who would police community boundaries. As an archetypal Status Function Declaration-an act that makes something the case by representing it as being the case-naming is a function that can be performed 'only in virtue of the fact that there is a recognised status of the object or the person that performs the function' (Searle 2015: 145), and it is just such a status that may be lacking in cases of secular (re)naming, as we shall see. Such a focus on debates and criticisms both within and outside the movement about the worth and validity of particular naming strategies is key for clarifying what is at stake in the domain of secular naming practices.

\section{Prior innovations}

11 It is important to be clear that present-day secularists are far from being the first or only individuals to identify the name as a problem or to mark it as an explicit matter of concern and questioning. ${ }^{3}$ What we might call 'transcategorial onomastics' ${ }^{4}$-an onomastics to dethrone the algorithm, so to speak-is both varied and longstanding, from Guru Gobind Singh's hailing of three Shudras, a Brahmin and a Kshatriya as 'Singhs' ${ }^{5}$ in forming the Sikh khalsa (Cunningham 1849: 70), to present-day deaf Indians' disavowal of caste or religious monikers in favour of ones denoting a particular bodily feature (Friedner n.d.; cf. Steinberg this issue), from the use of generics such as 'Kumar' ${ }^{6}$ to characters in twentieth-century Hindi novels going by single names only as a means of facilitating identification with them whatever the reader's background [Gold 2015]), and similarly the preponderance of characters in Hindi film who have been 'surnameless and thus regionless, casteless, ethnically non-identifiable, and [in Nandy's opinion at least] ultimately ahistorical' (Nandy cited in Charkavarty 1993: 200).

Yet such alleged ahistoricism I would suggest is very historically situated indeed-it is no coincidence that the surnameless characters in Hindi fiction and films are coeval with an era of patriotic nation-building in which caste and religious differences were downplayed in many circumstances in favour of pan-Indian generics. This could take the form of suppression of caste identifiers as in the case of the maternal uncle of a middle-aged teacher friend of mine in Delhi who, a communist party member, had in the 1960s given up the caste surname Gupta and adopted Bharti (Indian) 'because he wanted a casteless 
society,' or of nationalist boundary-crossing names as in the famous case of revolutionary fighter Udham Singh who, when arrested for the murder of Michael O'Dwyer, who had been lieutenant-governor of the Punjab in 1919 when the Jalianwala Bagh massacre took place, gave the boundary-crossing nationalist name Ram Mohammad Singh Azad, 'a name that invoked the three major religious communities of the Punjab-Hindu, Muslim, and Sikh-as well as his anticolonial sentiment (azad means "free")' (Mir 2010: 2-3).

In present times, Dalit migrants to the city may, for obvious reasons, take the opportunity migration affords to discard surnames that are often stigmatising (see Paik 2011: 236, Pandey 2013)-a practice that remains controversial both within and outside Dalit communities. ${ }^{7}$ Though many Dalits actively retain stigmatising caste surnames as acts of assertion and positive revaluation, Dalit and rationalist naming practices frequently overlap, sharing what might be termed a commitment to confusion. A north Delhi-based Dalit activist who uses a single name only-leaving a question mark where the usual caste title surname would be-put it to me like this: through naming practices such as his there will be 'So, so much confusion. Then the whole thing [that is, caste discrimination] will go away.' The expression he used was the Urdu 'ghaflat ho gayi.' Though in the following quotation-from a Christian Dalit acquaintance who retains his Christian forename having changed his surname to a perfectly ambiguous Hindu one that connotes different castes in different regions-the Hindi expression used was bhram: 'Some think I am Brahmin, some Kshatriya, some OBC, some Hindu, and those who know me know I am a Christian. It is good to confuse people. The upper castes have been befooling (bevakuf bana rahe hain) SCs for centuries, so if they are confused by the new Shuklas and Sharmas [i.e. Dalits taking on upper caste names] that is good' (emphasis added).

The intentional production of categorical uncertainty by way of experimental onomastics is thus not the preserve of rationalist activists. Much more could be said on the matter of a wider transcategorial onomastics not specific to rationalist activists, and its class basisfor instance, the kind of boundary-crossing names employed by upwardly mobile urban parents that signifies their sophisticated cosmopolitanism. The glossy Mumbai-based Mother and Baby magazine presents interviews with 'society' figures who do exactly thisMuslim actors whose new-born babies bear Hindu or Christian names and vice versa-and its founder-editor Priya Pathiyan told me about Hindu Sindhi friends of hers who live in south Delhi whose new-born they named Zyaan: global citizens, 'they are comfortable giving their baby a name that has roots in Arabic, ignoring older family members who ask "why a Muslim name?"' Contemporary secular naming practices sometimes reflect both this class dimension (many-though certainly not all-activists belong to 'respectable' professions such as medicine and academia) and that of nationalism-for instance, the son of a Punjabi rationalist leader is named Vishav Bharti (World Indian), and I shall describe similar instances of boundary-crossing names to that of Udham Singh belowwhich begs the question: are their naming acts mere remnants of a waning Nehruvian-era nationalist identity (i.e. a kind of onomastic 'national integration')? Is there anything vital or 'contemporary' about them or are such names teetering objects of nostalgia-without import in the so-called 'new India'?

15 The question becomes more pressing still in light of the way in which the politics of unrecognition, or reverse identity politics, I am concerned with here would seem quite at odds with the post Indian nationalist tendency toward differentiation as identified in a plethora of influential works from V.S. Naipaul's A Million Mutinies Now (1990) to Jaffrelot's The Silent Revolution (2003). The latter work charts the rise of caste-based political 
formations in the country consequent on the years preceding the 1975-77 Emergency when the Congress's populist goals 'had come to be expressed in terms which [...] signalled the importance of jati and varna [i.e. caste] classifications to anyone who could be thought of as wronged or deprived' (Bayly 1999: 285, see also Kapila 2008). My suggestion is that it is precisely because the dominant analytical narrative has focused on heightenings of difference that we should take seriously secular naming innovations as containing the possibility of delineating a countervailing trend towards more broadbased national or non-particularising identities-a trend that risks neglect given the existing scholarly emphasis on differentiated particularities. It is not just that a transcategorial imaginary still exists, but that it is evolving in new and interesting ways and onomastics are at its heart.

There is a further reason we should pay attention here. Activists' rationalism is frequently dismissed as 'the basis of hypocritical scorn for the less well educated and their superstitions' (Feuchtwang 2013: 86), with activists themselves accused of being nothing other than Macauley's grandchildren (a stance shared by the Hindu right and many scholars [Quack 2012b]). The material presented here allows us to progress beyond such stereotypes. The colonial regime-whose mantle activists are said to have inherited -famously inaugurated the governmentalisation of difference with massive continuing ramifications to this day, and scholars have been active in pointing out the role of enumeration in formalizing what had previously been 'fuzzy' communities (Kaviraj 1989) and how the competition between these newly identifiable interest groups resulted in a direct and singular equation between enumeration on the one hand and reification and fissiparity on the other. The reverse identity politics of 'Macauley's grandchildren' is therefore of note. In their politics of unrecognition we might discern an onomastic method of hope (Miyazaki 2004), or prefigurative (Graeber 2002) politics of the name. Omvedt, in 2010, wrote movingly of 'Waiting for an India when caste names will have lost their meaning: 'Perhaps [such] names might remain-after all, the US and England have Smiths, Carpenters, Potters-but in India, as there, no one would remember that they mean anything.' The activists discussed here refuse to wait. Seeking to produce the transcategorial in specific local instances, activists prefigure and foreshadow a future they simultaneously help to bring into being-a prefigurative politics of the name.

\section{Strategy 1}

The first strategy I term purificatory. It seeks to remove caste and religious connotations from the names activists themselves bear or that they give to their children. Omvedt (2010), as just noted, hopes that the caste connotations of many Indian surnames will be forgotten and become what Jullian (cited in Wilson 1998) in 1919 called 'sterilized words.' Activists, however, seek to accelerate the process of onomastic sterilization through active removal of such connotations.

18 Given their anti-caste convictions it is unsurprising that the removal of caste surnames is a common practice amongst them. Sometimes, as was mentioned earlier, dropping a caste surname is a condition of membership of local rationalist organizations. Activists may dispense with a surname altogether, use their place of origin as a (toponymic) surname, or adopt a 'place-holder' name such as Kumar or Singh. The founder of Tarksheel, the main Punjab rationalist society, changed his surname from Mittal, a caste title, to Mitter, meaning friend, a technique that retains an aural memory of the disavowed, ideologically 
unsound name (see Paik [2011: 236] on Dalit versions of this onomastic move and Mehta [this issue] on the spectrality of proper names).

Krishnan, an activist from central India, insisted to me that 'We should not expose religion in [our children's] names... Though I am from a Hindu background, I am not a Hindu-only a human being. My wife, who is also an activist, is from a Christian background, but she is not a Christian. We thought about it carefully and we called our elder son Lyric, and our younger son is called Sonnet.'

The use of English words as names allows parents to avoid an association with Sanskritderived names, for even if a Sanskrit name has no explicit religious reference point (e.g. unlike, for instance, the father's name Krishnan), the Hindu background of a person may be gauged by its Sanskrit origin (as with, for instance, Akash [sky]-not an explicitly 'religious' name but nonetheless typically revealing its bearer to be Hindu, or perhaps Jain or Sikh). This is similar to the situation of Muslims in Tamil Nadu: it is not that they do not see themselves as Tamils yet the association between Tamil and Hinduism causes them to choose non-Tamil names (Britto 1986). The drawback of this strategy, for secularrationalist activists, is that it is at odds with their attempts to emphasise that their project is one deeply embedded in Indian history as a counter to the Hindu right (and indeed scholarly) charge that they are inheritors of the colonial mantle. However, if the words are themselves 'un-Indian,' use of the related words Lyric and Sonnet does reflect the not uncommon north Indian practice of naming siblings in poetically similar ways, as in, for instance, calling three brothers Rachin, Sachin and Nitin.

21 Families associated with Vijayawada's Atheist Centre, ${ }^{9}$ provide further examples of the method of onomastic purification. This is what its literature has to say about rationalist naming practices:

Birth of a child, irrespective of gender, is a happy occasion for atheists and they share joy with others. They name their children as per the events in history, current and international affairs, social and political changes or reflecting the beauty of nature. In order to break the barriers of caste and religion, atheists name their children in a secular manner, connoting a meaning relevant to the time or an event which has no religious connotation. Taking the case of children in Atheist Centre, Samaram (II World War), Niyanta (dictator), Lavanam (Salt, was born on the eve of Gandhi's Salt Satyagraha), Vijayam (Victory. First success of Congress in General Elections), Vidya (Education) and the younger generation with unique names such as Sanketh (Information), Vidwat (Knowledge), Saujas (Redoubled Vigour and Youthfulness), Saaras \& Tejas (Indigenous manned aeroplanes developed by India), Olos (Olympics Los Angeles) to mention a few. Many atheists are making the next generation secular and post religious. Atheists also stress on the need for birth registration, which is neglected in India. When they admit their children in educational institutions, in the application forms they mention in the caste and religion column as 'nil' (Vijayam n.d.).

The examples provided here of names intended to 'break the barriers of caste and religion' are both international and national(ist) in outlook, with references to the Second World War, the Los Angeles Olympic Games, Gandhi's salt march and the development of 'indigenous' airplanes. Replacing caste and religious connotations with nationalist ones is a well-worn integrative move-it recalls, for instance, the 'Meri Jaati Hindustani' (My Caste is Indian) movement, which encourages Indians to write 'Hindustani' as their caste at census time,${ }^{10}$ and the very publicly visible use of 'Bharti' and 'Swaraj' as nationalist surnames. And as with Lyric and Sonnet, the pattern of naming enacted here is simultaneously innovative and conventional: Olos, for instance, is certainly unique, yet 
follows the classic Indian template of context-sensitive (Ramanujan 1989) naming, wherein children are named after the day on which they were born (Itvari, Manglu etc.) and former Bihar Chief Minister Laloo Prasad Yadav and his wife Babri 'named their first daughter Misa after the 1973 Maintenance of Internal Security Act that [Indira] Gandhi used to quell all opposition during the Emergency' (Cohen 2008: 36). These, then, are attempts-partial but meaningful-at onomastic purification; secular innovations that nonetheless emerge from and reflect existing naming conventions. ${ }^{11}$

There are multiple ways in which rationalists across time and space have sought to purify selves, spaces and events of religious iconography-in present-day England, for instance, 'the first thing that a [Humanist] celebrant does, when he or she arrives at the chapel [to conduct a funeral], is take away or have covered any religious symbols that may be present' (Engelke 2015a:39) -and the giving of names that seek to avoid religious connotations is on the face of it an onomastic variant of the practice. Moreover, onomastic purification can take many different forms and arise from quite different motivations. Restricting ourselves to South Asia, there is the case of the Viduthalai Ciruthaigal Katchi (VCK-Liberation Panther Party)-the largest Dalit movement in Tamil Nadu-whose embrace of Tamil nationalism has involved a mass campaign to deSanskritise personal names (Roberts 2010, see also Ramaswamy 1997), while Pakistan is seeing an increasingly purist attitude towards Islamic naming, with Wahabi-influenced moves to ban nicknames, names determined by numerology and even names 'implying that the prophet or saints bestow a child' (Rahman 2013:47). While some of this logic is no doubt exhibited in the case of Indian rationalists who in other contexts certainly make it their business to expunge religious symbolism, a critical difference is that in this case purification concerns less a move toward secular or rationalist piety or virtue than a move towards productive not-knowing and disidentification. Use of the term 'purification' here must therefore be nuanced. Unlike the Hindu social worker in Steinberg's essay (this issue) who removes Azeez from the child runaway Akhil-Azeez's hitherto ambiguous and situationally changeable name because 'she did not want to give him a Muslim name,' and schoolteachers in the Sunderbans who similarly Hinduise the Islamic inflections of pupils' ambiguous boundary-crossing names in class registers (Jalais 2009: 56), the strategy in this case is not one of either/or, or even both/and, but neither/ nor. Which is to say that here purification and commitment to confusion go together, with purification not aimed at narrowing down to a singular association (such as Tamil) but at the removal of all associations.

Since this is purification in the service of an 'open' name-open in the sense of seeking to pre-empt the way in which a name can pre-empt identity; keeping a child's options 'open' so to speak-this is indeed a very particular kind of purification. Das (this issue) refers to the 'open texture' of certain names and of names 'pregnant with future possibilities,' and the purified names given by rationalists similarly are an attempt to keep open a child's future possibilities.

Rationalists sometimes say that purified surnames such as No-caste are intended to provoke surprise and reflection on the part of hearers-'to make people think' as several activists put it to me-so we might say that they are a species of meta-name (indirectly pedagogical names meant to provoke reflection about the conventions of naming). It is difficult to gauge whether this intention is often, or even ever, fulfilled, but recognition of the intention is important in itself, and I can attest to the surprise they can generate. But there is a problem. Activists who do not go the route of purified names do not so 
much disapprove of such names as simply point out that many of them would be listed in Indian baby name books unambiguously under the 'Hindu' section. ${ }^{12}$ Consider the names Vikas (development), given since the boy was born during the First World Atheist Conference in 1972 which aimed to spread secular and atheist thought, and Sahasra (a new beginning), given in connection with the Arab Spring and what seemed then to be the burgeoning spirit of democracy in the Arab world. While they do not disclose the person's caste or necessarily refer to gods or Hindu concepts, their Sanskrit-derivation means they are nonetheless strongly indicative of this tradition. Activists work toward a function of names correlative with Mill's (1843) sense of them as being 'meaningless marks set upon things [or persons] to distinguish them from one another,' which is not to say that the name has no lexical meaning but that 'whatever lexical meaning it may have had, or still retains, does not interfere with its denotative function' (Nicolaisen 1978: 42). The problem of course is that particular communities are frequently associated with particular languages, whatever the lexical meanings of the words used as names, and whether or not such an association has to some extent been formed via indigenist appropriation (Pollock 2011: 40).

However, a television advertisement shows one imagined solution to the problem, and I conclude this section by describing it. The ad, aired in 2008, was for the Indian mobile phone company Idea Cellular, and featured film actor Abhishek Bachchan, son of Bollywood icon Amitabh. Set in an unspecified part of rural India it depicts caste-based strife between two fictitious village communities, the Thumihars and the Purmis. Then an idea strikes. "The sarpanch [head] of the village, played by Abhishek [...], declares that, henceforth, no one will be known as a Purmi or a Thumihar. Everyone will be known by a number. The ad goes on to show every person being known by a nine-digit number that starts with 9 and it stops the fighting in the village as people forget their caste identities.' 13

Helpfully reminding us that present-day transcategorial fantasies are not the preserve of rationalist activists, the solution the ad proposes is to move beyond words and language; i.e. to 'purely' denote through use of number. Consider also the Aadhaar biometric identity card scheme in which every citizen in India is assigned a 12-digit individual identification number to serve as proof of identity. Cohen (2012a) notes that part of the promise of the number is precisely that it might produce de-territorialised identities free of biography: finger prints, eye photos and indeed numbers rather than names: freedom from identity. But of course, and for good reason, reduction to a number is usually seen as being precisely that-an acutely negative reduction. Prisoner tattoos in late nineteenth century India inscribed a number made up of the prisoner's date of conviction and a serial number (Singha 2000), and there are of course many other notorious instances of reductive numeric inscription from the century after. De Certeau (2007:162) has complained of the replacement of local street names-a world of folklore, stories and legends that nurtures our collective memory-by numbers, just as 'on the telephone, one no longer dials Opera, but 073.' The expunging of stories and legends by arbitrary numeric combinations causes the city to become a 'suspended symbolic order' (ibid), and for de Certeau this is to be lamented.

However, if an onomastic symbolic order upholds a structure of discrimination and domination, it is not difficult to see why activists and those affected might actively pursue its suspension and even view substitution by numbers as a very productive reduction indeed. We need, of course, to be cautious on the question of whether number 
is in actual fact purely referential, while according recognition to others' conceptions of it as such. Maurer (2003: 318) usefully questions whether 'conversion to number' is always and everywhere a straightforward reduction. Invoking Wittgenstein, Maurer notes ways in which numbers may take on rhetorical functions, especially in respect of their putative 'reduction' to equivalence (Maurer 2003:319). Similarly, if we consider number's reduction to equivalence a 'form of argument' (Maurer 2003: 319)-part of the fantasy work of money, in Maurer's analysis-then we might understand nominative uses of number (i.e. numbers as names) as a means of producing equivalence of identities: a veritable 'fraternization of impossibilities' (Marx 1977: 110), but here positively valued. Numeric equivalence in names, as in money, seems to contain the possibility of 'rendering dissimilars into species of the same' (Maurer 2003: 332). In other words, it is precisely the connotative power of number (its rendering equivalent) that allows it to be mobilised as a fantasy of pure denotation.

\section{Strategy 2} outh and Muslim-origin activists have been central in the twentieth-century history of the rationalist movement, most activists I met were from Hindu or Sikh backgrounds, and it was notable how many of them gave their children recognisably Islamic names. Medical doctor Narendra Dabholkar, the founder of the main rationalist society in Maharashtra and staunch secular campaigner whose murder in 2013 was internationally reported, gave his son the Islamic name Hamid-probably in honour of Hamid Dalwai, who in 1977 founded the Indian Secular Society (Quack 2012b: 101). Of a saraswat Brahmin background, Narendra Dabholkar had already replaced his original caste title surname with one indicating his place of origin. His son's name, then, was doubly transcategorial. Dabholkar's fellow Maharashtrian rationalist and Marathi film actor Shriram Lagoo gave his son the Islamic name Tanveer, while Kalanathan, a Keralan activist, and his wife, named their son Shameel. As Kalanathan put it to me, 'I was born as a Hindu but I am not a Hindu-I am a human. I want to make a confusion so they can't identify a person's religion by their name. Only then will it go away. I say to [my son], use both names-[Hindu] Kalanathan as well as [Islamic] Shameel..$^{14}$ Then no-one will know what you are, everyone will be confused.'

As was noted above, there are places, times and communities in which boundary-crossing names are quite conventional and do not form statements of secularism or participate in a project to problematise conventional categories. The intentional hybridity (Marsland 2007) of the secular boundary-crossing name is consequent on prior deeds of purification that constitute this brand of secular naming as the act of bringing the separated categories into relation (see Maurer 2003). My sense, from travelling with 
activists from town to town in Bihar, Karnataka and Maharashtra on science education campaigns, is that boundary-crossing names have a higher capacity than purified names to surprise those who encounter them. In this recombinatory onomastics surprise is produced through unexpected juxtaposition. If surprise is often an occasion for generating new concepts (Street \& Copeman 2014:13, 18), here it is a technique for disrupting older ones. In this sense, the capacity of boundary-crossing names to enact a 'pedagogy of the name' is more pronounced than those characteristic of strategy 1 . In part this is because rationalists share the latter strategy with many non-rationalists who practice it for other (most commonly caste-obviating) reasons, whereas boundarycrossing names are more particular to rationalists. Similarly, though a significant minority of activists has adopted boundary-crossing names for either themselves or their children, such names are not as frequently used as purified ones.

Though the logics informing them overlap, there are obvious tensions between the two strategies considered thus far. In particular, purifiers may be disparaging about the boundary-crossing strategy of naming in such a way that retains religious connotations. As one Punjabi activist put it to me, 'Changing one religious name to another religious name is not a solution to the problem.' Such naming practices might produce helpful confusion but they do not move one away from 'religion' per se. The purifiers, as we know, seek out names without religious connotations, though boundary-crossers are quick to point out that they rarely achieve this. Sahasra, as we have seen, may not refer explicitly to a religious concept, but is categorised as a Hindu name in Indian baby name guides. The two strategies seem to reflect a tension between varieties of secularism: Purified names seem to reflect onomastically the separatist agenda of rationalist umbrella organization the Federation of Indian Rationalist Associations (FIRA) which campaigns on a national level for a stricter separation between state and religion. On the other hand, boundary-crossing names would seem to reflect the 'other' secularism-the accommodative, liberal pluralist one still widely viewed as having its roots in 'Hindu tolerance' (see Smith 1963) and whose three salient principles have been described as: 'religious freedom, celebratory neutrality and reformatory justice' (Dhavan 1999: 48).

Indeed, the two strategies do, I think, reflect wider tensions in the interpretation and implementation of 'secularism' both within and outside the rationalist fold. But for such a claim to be satisfactory it requires qualification. An analytic of 'reflection' does not do justice to the intentions of namers for the names they give to produce effects in the world. The transcategorialism of secular names is meant to transform the world (dethrone the algorithm) rather than simply reflect abstract rival doctrines of political thought. Such names do represent two key ways of conceptualizing secularism, but they are also acts of definition in Holbraad's (2012: xxiii) sense.

Such a sense of the capacity of names to produce effects in the world marks the act of naming as the staging of an intervention. Rationalist uses of boundary-crossing names define a space where the rather abstract political precepts of accommodative liberal pluralism meet the everyday intimacy of domestic usage, in which a name's repetition seems at once to dilute and concentrate its associations, which is to say that such repetition makes those associations ordinary (at least according to the namer's intentions). Naming, in such instances, can arise from an intention of making a relation to the other ordinary, or be informed by reflection on 'the notion of the possibility of being in the place where the Other is' (Duranti 2010: 16). So again, secular names do not simply reflect an ideology but are designed to iteratively produce a particular kind of 
intersubjective sensibility. Consider the case described by Banerjee (2008: iv) of Hindu parents giving their child an Islamic name. Informing the parents' decision was a desire to force themselves to use these names with love rather than with hate. Having themselves been profoundly affected by communal violence, the parents named their child in a way that served as a prophylactic against the lure of othering. Here the pedagogy of the name is directed as much at the name-giver as a reminder (an onomastic 'note to self') as it is to strangers, and differs from the meta-name in operating through repetition rather than through calling attention to itself as a name (though boundarycrossing names can do this, too, as we have seen). The Hindu-background activists I know who have given Islamic or Christian names to their children, which perforce are subject to continual repetition, did so as a kind of secular technology of the self to avoid othering a community that their political opponents have no compunction about de-humanizing and as recognition of its temptation. As one activist put it to me, 'Everyday and many times I say it. The [Islamic] name reminds us [the child's parents]: we should not follow the media and others and scapegoat this community for votes; we're all Indians.'

It is important and necessary to recognise parents' intentions here, and the nuanced reflections that inform their acts of naming. But what are the effects of such names? What kind of responses do such names engender? Given the Hindu provenance of most activists, one could make a case that boundary-crossing names operate (ironically) through a classical Hindu mode of laying claim to, and incorporating, otherness. We might ask: what makes the other available for incorporation in this way? What sorts of power relations inhere? Are Muslims in a position to object? I do not mean to imply that they would object if only given the chance but it is nevertheless important to acknowledge the structure of possibilities here. Hindus may happily go to a church and light candles (and this may be seen as a testament to the greatness and inclusiveness of Hinduism). But such inclusiveness also constructs religion as such in a certain way, one that may be just as dogmatic and imperial as more exclusive forms of worship. ${ }^{15}$ Are syncretic names, then, "code word[s] for the incorporation and assimilation of "minority" cultures into the culture of the dominant group' (Viswanathan 1995: 21)? We need to both take seriously activists' professed aims in employing such names-which as we have seen, primarily concern the desirability of confusion and dis-identity and of making a relation to the other ordinary-and thereby avoid reducing this onomastics to the status of mere symptom of a Hindu rationalism (which would be to dismiss activists' own sense of their actions and typify what Engelke [2015b] calls a 'gotcha' argument), and pay heed to the possibility that this is how others may perceive such usages and to the recognition that certain kinds of (not necessarily rationalist) boundary-crossing name may indeed form part of the semiotics of an imposed 'order of unity' (Viswanathan 1995). Certainly, boundary-crossing names are markedly differentiated. Consider, for instance, the multiple associations of the name of contemporary north Indian guru Gurmeet Ram Rahim Singh Ji Insan-this, I suggest, is a name that enfolds; being suggestive both of the bhakti universalism his movement espouses and of the guru as embodied confluence (Das 2014a) of different religious traditions. Accusations of appropriation do form a response to the rationalist boundary-crossing name, as we shall see; however, their source is not the community that at first glance we might consider the subject of appropriation, but the Hindu right.

It is not a straightforward matter to discern how 'everyday Muslims'-as if such a category were stable and meaningful across a range of disparate situations, regions and 
discourses (Cohen 2012b: 101) - view such uses of 'their' names by Hindu-background rationalists. The Muslim-background rationalists I know either shrug or applaud, which is unsurprising given their affiliation with the movement. A few themselves possess boundary-crossing names (which, notably, in several cases include a Christian first name and 'Singh'-a generic, but with Rajput and/or Sikh connotations). In the limited instances in which I have been able to observe Muslim-strangers' first encounters with rationalist boundary-crossing names-for instance, when signing in at a guesthouse or in conversation in a train carriage-a certain puzzlement and/or suspicion that that name is false resulted. In one case, in a busy carriage on Mumbai's Central Line, on learning the name of the activist I was accompanying the Muslim passenger politely enquired about the rationalist's parents: had they belonged to the nationalist movement? (Freedom fighter Udham Singh's boundary-crossing name was referred to above, but consider also the great Bengali literary icon, Kazi Nazrul Islam, whose patriotic songs and poems advocated communal harmony. His children's names-Krishna Mohammad, Arindam Khaled, Kazi Sabyasachi and Kazi Aniruddha-were a tapestry of Arabic and Sanskrit, Hindu and Islamic connotations).

\section{Inter-marriage/inter-name}

Another common response upon hearing a boundary-crossing name, from Muslims and non-Muslims alike, is to enquire-and the level of discretion here varies widely!-as to whether the bearer's parents had a love-match (i.e. an inter-religious marriage). Mines (1998: 238) has noted that the offspring of inter-faith marriages in Tamil Nadu frequently bear boundary-crossing names reflecting the different religious backgrounds of their parents. This is also witnessed in the names borne by the children of Bollywood icon Shahrukh and Gauri Khan (see epigraph). This is an interesting case for several reasons: like the names of other offspring of 'love-matches' the names Aryan and Suhana Khan bear a trace of the 'modernist' conjugal production of the child as the joint achievement of both parents in which they see 'novel combinations of themselves' and an objectification of their love (Strathern 1992: 55, 78), coded onomastically here in the 'nextness' of names that indicate their different religious backgrounds: 'We are a HinduMuslim family,' Shahrukh Khan notes. But he also calls attention to the 'secularism' of the name of his most recent child: 'I liked the connotation that [AbRam's]...a secular name.' This points towards the common understanding that all inter-faith marriages are to some degree 'secular' in signifying an ability to transcend conventional divisions, and it is worth noting here that most Indian rationalist organisations claim to offer financial and legal support to couples who have performed them in the face of familial opposition. The offers of assistance made by rationalist groups show their sympathy for inter-faith marriages, but of course the majority of such marriages do not arise from anything so grand as an ideological position on secularism taken up by the couple. Though less widespread than it once was, some incoming brides in north India change (or have changed for them) their forename as well as surname to mark their new circumstances. Inter-faith or -caste marriages, too, may occasion the bride changing her name to efface the boundary crossing the relationship embodied in a kind of post-hoc imposition of propriety. In light of this, we come to apprehend the critical role of the boundarycrossing name: a child's inter-name, in making the inter-marriage explicit, retroactively causes the inter-marriage to form a secular statement. The inter-name of the 'love- 
match,' then, may be indicative of secularism in a lower key, and rationalists indeed encounter inter-faith marriages as a form of lived secularism. If and when couples, too, come to understand their own conjugal trajectories in such a way, their children's names may signify both the complex unity of their 'separate' identities within the child and a kind of statement that reflects back on the 'secularism' of the union it emerges from.

Shahrukh Khan is himself extremely cognisant of the capacity of personal names to effect automatic categorisation. A recent film of his on the racial profiling of Muslims after the 9/11 attacks on New York foregrounded the highly suggestive statement, 'My name is Khan and I am not a terrorist,' and at an airport in New York to promote the same film, right on cue, the star was detained for questioning for two hours 'because his name came up on a computer alert list." 16 "'I was really hassled-perhaps because of my name being Khan," he said in a text message to reporters in India. "These guys just wouldn't let me through." ${ }^{17}$ This episode, and the detentions that he (like so many others with Islamic names) has been subjected to before and since, adds poignancy to the name he and Gauri Khan gave to their most recent child: AbRam. A particularly innovative 'intername' in the way it crosses boundaries within the forename itself, and also remarkable for the public debate it generated, I want to dwell for a moment on the way in which it mobilises the figure of Abraham in reference to a Hindu god. A report titled 'Secularism Shows in the Name of "AbRam,"” 18 quotes the actor: "'As we all know my wife Gauri is from Hindu family and me Muslim, by this so many issues arose but we are far from those issues now. We decided that our baby's name should show secularism so we have decided to give the name to [our] new-born baby "AbRam". Here "Ab" stands for our Prophet "Huzoor Abraham Alai-His-Salam" and "Ram" stands for as we all know Bhagwan "Ram."

Abraham is of course a kind of go-to figure of promise for progressive faith commentators for whom, as the root of the Abrahamic faiths, he stands for the possibility of healing and accord between the religions he 'fathered.' For Derrida (2007: 1-2), the 'serial multiplicity of the "more than one [plus d'un]" inscribed itself upon the very name of Abraham,' and it is in meditating upon the iconic progenitor's name that he produces an analytic of 'fidélité à plus d'un [faithfulness to more than one or: collective faithfulness]' (Derrida 2007: 14) and of what I interpret as names that may afford hospitality. One can see the attraction for Derrida of a figure that seems quite in tune with his own 'reasoned distrust toward borders and oppositional distinctions (whether conceptual or not)' (Derrida 2007: 17). Indeed, Abraham is equated by Derrida with 'the endurance of the undecideable' (Derrida 2007: 17), just as the focus here has been on an onomastics of undecideability as a counter to automatic categorisation, and a hospitality extended to 'the other in me.' AbRam is, of course, just such an undecideable, even hospitable, name. Its audacity lies in onomastic extension of the lineage, with the 'Ab' brought together with 'Ram,' the name of a Hindu god. Thus is non-Abrahamic Hinduism integrated into an imagined Abrahamic secularism.

\section{Disapproval}

Mines (1998: 238) noted how children of inter-faith marriages bearing boundary-crossing names were teased by schoolteachers who 'both disapproved [of] and were titillated by [their parents'] union,' and activists' children bearing this kind of name can be met with similar responses. Such names might be given with worthy transcategorial and/or pedagogical intentions, but cause those who perforce bear them some misery and 
embarrassment. Dabholkar's son Hamid is said to have 'suffered a lot in college because of his name. Everyone asked him, "What is your caste? What is your caste?" ${ }^{19}$ While in the case referred to above in which avowedly secular parents gave a Hindu boy an Islamic name, the child later demanded to be given a new, unambiguously Hindu name due to teasing at school (Banerjee 2008). If the illocutionary force of naming acts is 'felicitous [only] when the context is in place and our trust in conventions is secure' (Das 2007: 178), the absence of these factors in respect of unconventional, or extraordinary, acts of naming such as these disrupts their efficacy. The boundary-crossing name is in part interventionist-intended to eventuate the disidentity it embodies-but also normative in depicting what transcategorialism ideally should be like (and as such at odds with ordinary naming conventions). But similar to philosophical writings that create a normative base for discussing what various phenomena ideally should be like, with often little attempt to account for their everyday forms (Miller 2007: 546), boundary-crossing names will sometimes not fare well within the scenes of utterance into which they are inserted. In addition to the teasing of those who bear them, there is the even blunter instrument of simply refusing to use such names. A Kolkata-based, Hindu-background activist described to me how her non-rationalist family members ${ }^{20}$ do exactly this in respect of her daughter: that is, they ignore the Islamic name given to her by her parents, having between them-and quite independently of her parents-decided on a Hindu name for her that they would use. The activist is fearful that they may even have consulted a pandit for the purpose. Since making something the case by representing or declaring it as such only succeeds if the status of the actor performing the function is to some degree collectively recognised (Searle 2010: 7), one can see why rationalist acts of naming may fail to 'take' in families in which the tradition is to consult a pandit rather than leave the act of naming solely with the parents.

Refusals to acknowledge and/or scorning of boundary-crossing names thus form one of the major problems generated by rationalists' attempts to realign the problem of names and automatic categorisation. But the problems they face are not discrete and may overlap, which is what we find in the next illustrative example which concerns the name of the aforementioned film actor Shriram Lagoo.

\section{Paradoxical appropriation}

In the early 2000s, the actor-activist "was harassed by the hooligans of [the] RSS who insisted that he should change his first name because Shriram is God's name [but] he is an atheist. ${ }^{21}$ The origins of the controversy lie in Lagoo having written a piece called 'Retire the god' that served as the introduction to a new book on the noted Keralan/Sri Lankan rationalist Abraham Kavoor. ${ }^{22}$ It went further than Dabholkar's organisation was itself willing to go, at least publicly, on the question of the existence of God and the article inspired considerable public debate. Dabholkar and Lagoo then began a program they named Vivek Jagar (Knowledge Awakening) in which they staged debates across Maharashtra. Dabholkar (2001: 10) reports details of a specific confrontation between the actor and Hindu right activists that occurred immediately after a Vivek Jagar program at Sangli:

Dr. Lagoo wanted to go to Mumbai by night train. We, all the organizers, were at station to see him off. The train was late. During that period we saw a group of young people rushing towards Dr. Lagoo. At first we thought that the group may be 
fans of Doctor who also is a famous film actor... Within no time they surrounded us and started shouting slogans like Jai [i.e. victory to] Bhavani, Jai Shivaji; Sanatan Hindu Dharm ki Jai... They started asking questions like, Why do you speak against Hindu religion?... One of them suggested that Dr. Lagoo should shout Jai Shri Ram. Dr. Lagoo was not afraid at all. He must have thought himself and with a smile on his face he said 'Jai Shri Ram' and after a pause added 'Lagoo' to it. The slogan became 'Jai Shri Ram Lagoo.' Even in those strenuous moments we could not help laughing. All these angry young men were confused. At that moment the train entered the platform and Dr. Lagoo boarded the train. Thus further confrontation was avoided.

Lagoo's forename Shriram presents a paradox, since his use of it is at odds with both of the strategies we have considered: neither purified nor boundary-crossing, the name Shriram Lagoo unambiguously encodes its bearer's Hindu background. No change, or renaming, has taken place to cause offence-it is his continued use of the name that seems to be the problem. (Indeed, as the foregoing examples indicate, the objects of the majority of rationalists' naming innovations are their children, as with Lagoo's son Tanveer). If his own name became a matter of concern due to his very public atheism, part of Lagoo's rationale for preserving it is sentimental: 'As a child I...was not [in] a position to oppose my parents not to give God's name to me. They were very pious parents and as such they might have chosen the God's name for their beloved child. They have given me name with their love and affection' (cited in Dabholkar 2001: 10). There are also practical concerns: 'Atheists do not like to be called by God's name, [but] there is no simple and easy escape route for them,' one activist told me. ${ }^{23}$ Another stated: 'More than 10 million people have gods in their names. Some are Bhagwan or Paramatma Singh, even Ram-there are so many. But I have not chosen my name. My parents gave me my name. I became a rationalist later on in life. So how can I change it?'

The Hindu right activists who threatened Lagoo, however, apparently consider his mere continuing to bear a name that he did not choose for himself an active appropriation of it. From such an angle, his name may indeed be construed as boundary crossing: a rationalist, he nonetheless bears a notably Hindu name. Lévi-Strauss (1966) famously noted how 'Some societies jealously watch over their names,' and countless ethnographic examples could be given that show how names are frequently understood as items of property. Part of the problem, of course, is that Shriram is not just a Hindu-identifying name but a god's name-and one that the Hindu right has expended a large amount of energy defending in recent decades. Moreover, in certain bhakti schools there is considerable slippage between the name and deity, with mantras inseparable from the gods whose names they speak (Wilke and Moebus 2011:571). So as with the lesbian character Sita in the film Fire (1998) whose name was changed to Nita in response to violent Hindu right protests, 'defence' of the name seems to constitute defence of the god him or herself. If 'stories told about objects of use belong to their aura' (Das 2014b: 294), we might say that in seeking to hinder the attachment of Lagoo's rationalist crusading to the name object he carries Hindu activists seek copyright protection of the (Hindu) name's aura. They are seeking to manage (and contain) the name's associations-a delimiting that mirrors rationalist activists' own attempts to generate expulsive or purified names.

Notwithstanding Jaffrelot's (2008) powerful argument concerning the learned, or instrumental, nature of Hindutva's 'taking offence,' it is possible to perceive why a person with the name Shriram proclaiming the need to 'retire the god' might be construed as 
incongruous for some. Of course, as with brand names (Mazzarella, this issue), accruing improper associations is a risk built into the very existence of personal names. Just as 'brand jacking' demonstrates that a product is 'never able to legislate its own intelligibility completely' (Nakassis 2013: 121), intentionally incongruous name uses can be taken up as a form of political assertion. Consider the case of controversial right-wing Slovenian politician and former prime minister, Janez Janša, whose statement in 2007 that 'the more there will be of us [i.e. Slovenians as opposed to immigrants] the sooner we shall reach the goal' was responded to with ironic literalism when three Slovenian performance artists legally renamed themselves Janez Janša. The act of naming doubly performative (in Austin's and in the artistic sense), the artists' subsequent engagement in activities incongruous with the names they bore constituted an indirect but potent form of political critique; for example, a headline 'Janez Janša Dances in Berlin,' which referred to an artistic performance by one of the three artists, had a double-meaning, since it could be interpreted as the Prime Minister being servile to German interests (Janša et al. 2008). ${ }^{24}$

46 I do not claim that such a logic animated Lagoo's retention of the name Shriram-no renaming took place, and his name is a matter of concern for Hindutva activists, not him. Yet the episode at the station in Sangli in which the actor-activist proclaimed 'Jai Shri Ram...Lagoo' certainly seemed to play on the gap between name and named and was evidently comical for Dabholkar and his colleagues. ${ }^{25}$ In his analysis of Bentham's 'autoicon'-the philosopher's bequeathal of his own stuffed corpse to University College, London in 1832-Collings (2000:124) sees in the gesture a 'delicious profanation' and 'a kind of sly joke against contemporary prejudice and outraged opinion' that calls upon 'the libidinal resources of debasement and traditional inversion rituals.' Is there something of this wilful transgression and inversion of convention in some rationalist acts of naming? Many activists take delight in staging their weddings on inauspicious days, feasting during eclipses, and consuming substances such as meat and alcohol that in many contexts are shunned as impure. The hinted at sense of wilful transgression-not frequently present, but perhaps animating the laughter at Sangli station-is suggestive of pleasurable incongruity, and of taking possession for ironic effect in a manner that contains parallels with the case of Janez Janša. Rather than brand jacking, it could be termed (or, more to the point, experienced by certain Hindu right activists as) "name jacking.'

\section{Conclusion}

This paper has sought to shed light on secular naming innovations through identifying and exploring two key strategies used by rationalist activists to deactivate the automatic categorisation of the name, and their problems. The two onomastic strategies-of purification on the one hand and boundary crossing on the other-aim to achieve similar ends, but pursue different means. The focus on their problems has not been because I view the strategies as flawed or the deeply held convictions informing them as not significant, but because it affords illumination of the differentiated nature and differently weighted priorities of Indian rationalist and secular campaigning, and the manner in which problem-solving can beget new kinds of problems. I conclude by pointing to a final way in which some secular names have been considered to be problematic. 

the comments section below an online newspaper report on the efforts of an NGO in Maharashtra to rename en masse the hundreds of girls in the state who had reportedly been named by their parents Nakusa (unwanted). ${ }^{26}$ The remark takes its place in a long line of commentary-from colonial times (Cohn 1996: 125), through to the mid twentiethcentury (Naipaul 1964) and beyond-that has sought to diagnose an Indian susceptibility to show and drama and preference for symbolic action over that which is substantive and effectual. The comment suggests that little will change for these rural girls as a result of their renaming: if they were unwanted before, they will likely remain so after. Similarly, when it was reported that thousands of Pakistani children were unable to access a state welfare scheme due to unknown parentage, and former president Asif Ali Zardari had offered them his own name for use in the otherwise empty father's name box, online commenters ridiculed the gesture: 'Can the children object?' 'Haven't the kids suffered enough?' 'He is screwing the whole country [...] he might as well lend his name to some of the children of the country that don't have names already.' It was ridiculed, in other words, because what these children really needed was not offered, only that which could be given without the giver giving anything up: 'If his "kids" can get a share of his property, then why not?' 'Is it only name, or education and other facilities same as his own children's [...] Surely he can afford it. ${ }^{27}$

This begs the question of the kind of adjacency, or hospitality, that a boundary-crossing name does and does not embody. Are they empty gestures? Does the adjacency figured in such a name pay 'attention to the concrete specificity of the other' (Das 2010:377), or is the other more of an abstract, theoretical presence? I think here of the middle class blood donors I met and discussed in previous work (Copeman 2009: 170) who declaim their progressive credentials in imagining their donated blood being transfused into, and merging with, the bodies of any others. Meanwhile, they do not inter-dine, and have extremely little day-to-day contact with people belonging to communities other than their own. Rather than a concrete and complicated presence, the other is considered abstractly in absentia. Boundary-crossing names-certainly those that do not originate from within inter-faith marriages-may reflect something of this sensibility, but I would wish to be cautious on this point. A good number of activists do indeed marry across religious boundaries, while we have seen that boundary-crossing names are often given with an intention of making a relation to the other ordinary. I do not claim that a family's endlessly repeated iteration of the name of the other as the name of its own is the same thing as participation in everyday networks of encounter, but that such an onomastics of recognition and non-recognition is worthy of our attention for its complex intertwining of the ordinary (enacted through a name's everyday iteration) and the attempt to aspire to a 'higher ideal' through systematic disruption of an onomastic order in which a name unproblematically defines its bearer.

50 Connected to this is the matter of caste names. 'The nationalist project,' writes Rege (2006: 31), 'mobilised modernity and [the] nation to make the public expression of caste illegitimate. As caste became the "other" of the modern, the modern secular Indian came to be imagined as one who publicly and politically disavowed caste. ${ }^{28}$ And arguably the simplest way to do this is to drop the caste surname. Many examples could be offered: consider how on many Indian campuses it is politically correct for students to substitute caste surnames with generics, and also very recent headlines that have focused on popular novelist Amish's decision to drop his caste surname, and the Himachal Pradesh 
police force decree that all its officers must do the same, and so on. ${ }^{29}$ In the light of analyses that view such onomastic moves as part of an urban middle class strategy to stop caste coming into the public sphere and thereby having to negotiate over its own position, the question again arises as to whether purified names partake of what Dirks (2001) calls 'the embarrassment of caste'-public denial of its significance (figured here by the absence of a caste surname) going hand in hand in the domestic sphere with persistence of caste-based marriages, and a multitude of other caste logics. Do rationalist onomastics enact a comparable covering over of the matter, a self-serving 'abolition by denial' (Chatterjee 2005) such that structures of discrimination are left in place but simply no longer talked about (named)?

The arguments of Rege (2006), Deshpande (2013) and Dirks (2001) are I think applicable to very many of the onomastic purifications engaged in by putatively secular-aligned individuals and organisations. But, again, we must be careful. Consider the criticisms, mentioned earlier, directed at campaigner-author Arundhati Roy in the wake of her new introduction to The Annihilation of Caste. Damned if she does and damned if she doesn't, she is criticised for retaining a caste surname; yet if she were to drop it she would likely be excoriated for covering it over-abolition by denial! People can have reasons for not naming caste other than self-serving ones arising from bad faith. In the case of rationalist activists, there are several reasons why their actions are not continuous with the middle class (and upper caste) strategy of stopping caste coming into public view. First, there is the pedagogy of the name that renders it an explicit object of reflection; second, their reaching, via the name, towards categorial undecideability is explicitly a means to combat automatic categorisation and the manifold forms of discrimination consequent on this and an attempt to reclaim an 'open texture' of the name so that it does not pre-empt a child's identity; and third, at its most ambitious it is a project of unravelling the knot of caste: rather than passively wait for people to forget the connotations of caste names, they enact a generative anti-mnemonics, or what might be described as a negative illocutionary force produced through a form of speech act that seeks to undo things with words.

\section{BIBLIOGRAPHY}

Alter, Adam (2013) Drunk Tank Pink: And Other Unexpected Forces that Shape How We Think, Feel, and Behave, London: Penguin.

Austin, J. L. (1962) How to Do Things With Words: The William James Lectures delivered at Harvard University in 1955 [Edited by James O. Urmson], Oxford: Clarendon Press.

Banerjee, Mukulika (2008) 'Introduction', in Mukulika Banerjee (ed.), Muslim Portraits: Everyday Lives in India, Delhi: Yoda Press, pp. xii-xv.

Bayly, Susan (1999) Caste, Society and Politics in India from the Eighteenth Century to the Modern Age, Cambridge: Cambridge University Press. 
Bertrand, Marianne; Mullainathan, Sendhil (2004) 'Are Emily And Greg More Employable than Lakisha and Jamal? A Field Experiment on Labor Market Discrimination', American Economic Review, 94(4), pp. 991-1013.

Bourdieu, Pierre (1991) 'Rites of Institution', in G. Raymond \& M. Adamson (trans.) Language and Symbolic Power, Cambridge: Polity Press.

Britto, Francis (1986) ‘Personal Names in Tamil Society’, Anthropological Linguistics, 28(3), pp. 34965.

Charkavarty, Sumita (1993) National Identity in Popular Indian Cinema 1947-1987, Austin: University of Texas Press.

Chatterjee, Indrani (2005) 'Abolition By Denial: The South Asian Example’, in Gwyn Campbell (ed.), Abolition and Its Aftermath in Indian Ocean Africa and Asia, New York: Routledge.

Cohen, Lawrence (2008) 'Science, Politics, and Dancing Boys: Propositions and Accounts', Parallax, 14(3), pp. 35-47.

Cohen, Lawrence (2012a) '1', Paper given at the Annual Conference on South Asia, Madison (Wisconsin), URL: http://followuidai.wordpress.com

Cohen, Lawrence (2012b) 'The Gay Guru: Fallibility, Unworldliness, and the Scene of Instruction', in Jacob Copeman and Aya Ikegame (eds.) The Guru in South Asia: New Interdisciplinary Perspectives, London: Routledge, pp. 97-112.

Cohn, Bernard (1996) Colonialism and Its Forms of Knowledge: The British in India, Princeton: Princeton University Press.

Collings, David (2000) 'Bentham's Auto-icon: Utilitarianism and the Evisceration of the Common Body’, Prose Studies, 23(3), pp. 95-127.

Copeman, Jacob (2009) Veins of Devotion: Blood Donation and Religious Experience in North India, New Brunswick (New Jersey): Rutgers University Press.

Cummins, Carole; Winter, Heather; Kar-Keung Cheng; Maric, Roger; Silcocks, Paul; Varghese, Cherian (1999) 'An Assessment of the Nam Pehchan Computer Program for the Identification of Names of South Asian Ethnic Origin', Journal of Public Health, 21(4), pp. 401-06.

Cunningham, Joseph Davey (1849) A History of the Sikhs: From the Origin of the Nation to the Battles of the Sutlej, Oxford: Oxford University Press.

Dabholkar, Narendra (2001) ‘The Episode of Jai Shriram (Lagoo)' Thought and Action, OctoberDecember, pp. 8-11.

Das, Veena (2007) Life and Words: Violence and the Descent into the Ordinary, California: University of California Press.

Das, Veena (2010) 'Engaging the Life of the Other: Love and Everyday Life', in Michael Lambek (ed.), Ordinary Ethics: Anthropology, Language and Action, New York: Fordham University Press, pp. 376-99.

Das, Veena (2014a) 'Cohabiting an Interreligious Milieu: Reflections on Religious Diversity', in Janice Boddy and Michael Lambek (eds.), A Companion to the Anthropology of Religion, Oxford: Blackwell, pp. 69-84.

Das, Veena (2014b) 'Action, Expression and Everyday Life: Recounting Household Events' in Veena Das, Michael Jackson, Arthur Kleinman and Bhrigupati Singh (eds.) The Ground Between: Anthropologists Engage Philosophy, Fordham: Fordham University Press. 
de Certeau, Michel (2007) 'Walking in the city', in Simon During (ed.) The Cultural Studies Reader, London: Routledge.

Derrida, Jacques (1988) 'Afterword: Toward An Ethic of Discussion', in S. Weber (trans.), Limited Inc., Evanston (Illinois): Northwestern University Press, pp. 111-60.

Derrida, Jacques (2007) ‘Abraham, the other', in B. Bergo, D. Cohen \& R. Zagury-Orly (eds.), Judeities: Questions for Jacques Derrida, New York: Fordham University Press, pp. 1-35.

Deshpande, Satish (2010) 'Caste Articulation: Three Lessons from the Creation of the OBC Category', Himal SouthAsian, April, URL: http://old.himalmag.com/component/content/ article/131-caste-articulation.html

Deshpande, Satish (2013) 'Caste and Castelessness: Towards a Biography of the "General Category"', Economic and Political Weekly, 48(15), pp. 32-9.

Dhavan, Rajeev (1999) 'The Road to Xanadu: India's Quest for Secularism', in K. N. Panikkar (ed.) The Concerned Indian's Guide to Communalism, New Delhi: Penguin.

Dirks, Nicholas B. (2001) Castes of Mind: Colonialism and the Making of Modern India, Princeton: Princeton University Press.

Duranti, Alessandro (2010) 'Husserl, Intersubjectivity and Anthropology', Anthropological Theory, 10(1-2), pp. 16-35.

Engelke, Matthew (2015a) 'The Coffin Question: Death and Materiality in Humanist Funerals', Material Religion, 11(1), pp. 26-48.

Engelke, Matthew (2015b) ‘Good without God. An Interview with Matthew Engelke', Kings Review, August, URL: www.kingsreview.co.uk/magazine/blog/2015/08/05/good-without-god-aninterview-with-matthew-engelke

Feuchtwang, Stephan (2013) 'The Bad, Fear and Blame? Comment on Bayly's Mapping Time, Living Space', Cambridge Anthropology, 31(2), pp. 85-7.

Friedner, Michele (n.d. draft) 'How the Disabled Body Unites the National Body: Disability as "feel good" diversity in urban India'.

Goffman, Erving (1963) Stigma, Englewood Cliffs (New Jersey): Spectrum.

Gold, Daniel (2015) Provincial Hinduism, Oxford University Press: New York.

Graeber, David (2002) 'The New Anarchists’, New Left Review, 13(Jan-Feb), pp. 61-73.

Hick, John (2000) 'Ineffability', Religious Studies, 36, pp. 35-46.

Holbraad, Martin (2012) Truth in Motion: The Recursive Anthropology of Cuban Divination, Chicago: University of Chicago Press.

Ingold, Tim (2011) Being Alive: Essays on Movement, Knowledge and Description, London: Routledge.

Jaffrelot Christophe (2003) India's Silent Revolution: The Rise of the Low Castes in North Indian Politics, Delhi: Permanent Black.

Jaffrelot, Christophe (2008) 'Hindu Nationalism and the (Not So Easy) Art of Being Outraged: The Ram Setu Controversy', South Asia Multidisciplinary Academic Journal, 2, URL: http:// samaj.revues.org/1372.

Jalais, Annu (2014) Forest of Tigers: People, Politics and Environment in the Sundarbans, New Delhi: Routledge.

Janša, Janez; Janša, Janez; Janša, Janez (eds.) (2008) NAME Readymade, Ljubljana: Moderna Galerija. 
Kapila, Kriti (2008) 'The Measure of a Tribe: The Cultural Politics of Constitutional Reclassification in North India', Journal of the Royal Anthropological Institute, 14(1), pp. 117-34.

Kaviraj, Sudipta (1989) ‘On the Construction of Colonial Power: Structure, Discourse, Hegemony’, Delhi: Nehru Memorial Museum and Library (mimeographed).

Latour, Bruno (2005) Reassembling the Social: An Introduction to Actor-Network Theory, Oxford: Oxford University Press.

Lévi-Strauss, Claude (1966) The Savage Mind, Chicago: University of Chicago Press.

Marsland, Rebecca (2007) 'The Modern Traditional Healer: Locating “Hybridity” in Modern Traditional Medicine, Southern Tanzania', Journal of Southern African Studies, 33(4), pp. 751-65.

Marx, Gary T. (1999) 'What's in a Name? Some Reflections on the Sociology of Anonymity', The Information Society, 15(2), pp. 99-112.

Marx, Karl (1977 [1844]) 'Economic and Philosophic Manuscripts', in David McLellan (ed.), Karl Marx, Selected Writings, Oxford: Oxford University Press, pp. 75-112.

Maurer, Bill (2003) 'Uncanny Exchanges: The Possibilities and Failures of Making Change with Alternative Monetary Forms', Environment and Planning D, 21(3), pp. 317-40.

Mill, John Stuart (1974 [1843]) A System of Logic, Volume 7, London: Longmans.

Miller, Daniel (2007) ‘What is a Relationship? Is Kinship Negotiated Experience?’, Ethnos, 72(4), pp. 535-54.

Mines, Matisson (1998) 'Hindus at the Edge: Self-awareness Among Adult Children of Interfaith Marriages in Chennai, South India', International Journal of Hindu Studies, 2(2), pp. 223-48.

Miyazaki, Hirokazu (2004) The Method of Hope: Anthropology, Philosophy, and Fijian Knowledge, Stanford, CA: Stanford University Press.

Naipaul, V. S. (1964) An Area of Darkness, New York: Vintage.

Naipaul, V. S. (1990) India: A Million Mutinies Now, London: Picador.

Nakassis, Constantine V. (2013) 'Brands and their Surfeits', Cultural Anthropology, 28(1), pp. 11126.

Nanchahal, Kiran; Mangtani, Punam; Alston, Mark; dos Santos Silva, Isabel (2001) ‘Development and Validation of a Computerized South Asian Names and Group Recognition Algorithm (SANGRA) for Use in British Health-related Studies', Journal of Public Health, 23(4), pp. 278-85.

Nicolaisen, W.F.H. (1978) ‘Are There Connotative Names?’, Names, 26, pp. 40-47.

Omvedt, Gail (2010) 'The Caste Train: Waiting for an India When Caste Names Will Have Lost Their Meaning', Himal Southasian, April, URL: http://old.himalmag.com/component/content/ article/124-the-caste-train.html

Pollock, Sheldon (2011) 'Crisis in the Classics', Social Research, 78(1), pp. 21-48.

Quack, Johannes (2012a) ‘Organised Atheism in India: An Overview', Journal of Contemporary Religion, 27(1), pp. 67-85.

Quack, Johannes (2012b) Disenchanting India: Organized Rationalism and Criticism of Religion in India, New York: Oxford University Press.

Rabinow, Paul (2005) ‘Midst Anthropology's Problems', in Stephen Collier and Aihwa Ong (eds.) Global Assemblages: Technology, Politics, and Ethics as Anthropological Problems, Oxford: Blackwell. 
Rahman, Tariq (2013) 'Personal Names of Pakistani Muslims: An Essay on Onomastics', Pakistan Perspectives, 18(1), pp. 33-57.

Ramanujan, A. K. (1989) 'Is There an Indian Way of Thinking? An Informal Essay', Contributions to Indian Sociology, 23(1), pp. 41-58.

Ramaswamy, Sumathi (1997) Passions of the Tongue: Language Devotion in Tamil India, 1891-1970, Berkeley: University of California Press.

Rege, Sharmila (2006) Writing Caste, Writing Gender: Reading Dalit Women's Testimonies, Delhi: Zubaan.

Roberts, Nathaniel (2010) 'Language, Violence and the State: Writing Tamil Dalits', South Asia Multidisciplinary Academic Journal, January, URL: samaj.revues.org/index2952.html.

Roy, Arundhati (2014) 'The Doctor and the Saint', in S. Anand (ed.) Annihilation of Caste: The Annotated Critical Edition by B.R. Ambedkar, London: Verso.

Searle, John (2015) 'Performativity or Discourse? An Interview with John Searle', Theory, Culture \& Society, 32(3), pp. 135-47.

Searle, John (2010) Making the Social World: The Structure of Human Civilization, Oxford: Oxford University Press.

Sharma, D. D. (2005) Panorama of Indian Anthroponomy: An Historical, Socio-cultural and Linguistic Analysis of Indian Personal Names, Delhi: Mittal Publications.

Singha, Radhika (2000) ‘Settle, Mobilize, Verify: Identification Practices in Colonial India', Studies in History, 16(2), pp. 151-98.

Smith, Donald E. (1963) India as a Secular State, Princeton: Princeton University Press.

Srinivas, M.N. (2012 [1976]) The Remembered Village, Delhi: Oxford University Press.

Stewart, Tony K. (2000) 'Alternate Structures of Authority: Satya Pir on the Frontiers of Bengal', in David Gilmartin and Bruce B. Lawrence (eds.), Beyond Turk and Hindu: Rethinking Religious Identities in Islamicate South Asia, Florida: University Press of Florida, pp. 21-54.

Strathern, Marilyn (1992) After Nature: English Kinship in the late Twentieth Century, Cambridge: Cambridge University Press.

Street, Alice; Copeman, Jacob (2014) ‘Social Theory after Strathern: An Introduction', Theory, Culture \& Society, 31(2-3), pp. 7-37.

Susewind, Raphael (2014) 'What's in a Name? Probabilistic Inference of Religious Community from South Asian Names', Field Methods, Online First, DOI 1525822 X14564275.

Thorat, Sukhadeo; Attewell, Paul (2010) 'The Legacy of Social Exclusion: A Correspondence Study of Job Discrimination in India's Urban Private Sector', in Sukhadeo Thorat and Katherine S. Newman (eds.), Blocked by Caste: Economic Discrimination in Modern India, Delhi: Oxford University Press, pp. 35-51.

Viswanathan, Gauri (1995) 'Beyond Orientalism: Syncretism and the Politics of Knowledge', Stanford Humanities Review, 5(1), pp. 19-32.

Wilke, Annette; Moebus, Oliver (2011) Sound and Communication: An Aesthetic Cultural History of Sanskrit Hinduism (Vol. 41), Berlin: Walter de Gruyter. 


\section{NOTES}

1. In parts of north India they do in fact signify a caste identity. In metropolitan cities, however, they are unlikely to.

2. This research commenced in 2009 when I spent several months shadowing activists as they travelled through rural Bihar and Karnataka conducting science education and miracle debunking programmes, and is on-going. Since then I have visited rationalist associations and events in Punjab, Maharashtra, Gujarat, Tamil Nadu, Delhi and Uttar Pradesh, and the research has included attendance at one-off events (such as state- and national-level conferences and specific campaigns or protests) and regular participation in local networks (e.g. attendance of weekly meetings of a humanist society in Delhi). As with rationalist organizations globally, there is an unequal representation of the sexes in the Indian movement. Roughly, active women constitute less than a quarter of the group's membership. The caste make-up of activists is quite diverse, but the movement's leaders tend to hail from upper-caste and -class backgrounds.

3. The phrasing here borrows from Latour (2005).

4. Transcategoriality is a term I borrow from theologian Hick (2000) who proposes it as a substitute for 'ineffable', which for a number of reasons he sees as no longer being analytically useful.

5. Though arguably an act of 'Rajputisation.'

6. Though this status is regionally variable: it is a caste title/surname in parts of Uttar Pradesh.

7. To be explored in future work.

8. Interview, July 2013.

9. Further details on which may be found in Quack (2012a, 2012b: 89-91).

10. See Economic Times, 15 May 2010, and Deshpande's (2013) telling analysis.

11. Numerous further examples of names given after incidents co-occurring with the birth of the child are detailed by Sharma (2005: 111-112): e.g. a child named Tito after a state visit by the former Yugoslav statesman; another, born mid-air, named Akash (sky/space); a child named Missile Singh after his parents heard explosions caused by a fire at a makeshift ammunition depot near their home in Bikaner.

12. Indeed, 'Sahasra' is categorized as a Hindu name on the indiaparenting.com website.

13. India Today, 16 Nov. 2008.

14. This refers to the prevalent south Indian practice of using one's father's name as a surname.

15. I am indebted to Nathaniel Roberts for insisting I consider this matter.

16. Telegraph. 17 Aug. 2009.

17. Washington Post, 16 Aug. 2009.

18. http://bollybol.com/news/secularism-shows-in-the-name-of-abram-shah-rukh-khan/

19. Interview with Prabhakar Nanawaty, June 112013.

20. See Quack (2012a) on tensions within the families of activists whose relatives do not share their convictions.

21. Interview with Prabhakar Nanawaty, June 112013.

22. On whom see Quack (2012: 96-7).

23. Interview with Prabhakar Nanawaty, June 112013.

24. I am grateful to Matjaz Vidmar for drawing this case to my attention.

25. Delight in inappropriateness is certainly a feature of Indian rationalist humour, and extends to names. After large-scale corruption at the Andhra Pradesh-based IT-firm Satyam was revealed in 2009 much was made of the onomastic and other alleged telling connections between the firm and the now-deceased guru Satya Sai Saba, while the astrologer Satya Devatra, the 'Oracle of 
Gopur', was rechristened Asatya (Untruth/Lie) Devatra after his oracular claims were exposed as 'absolute nonsense.'

26. Wall Street Journal, 20 Oct. 2011.

27. The Nation, 15 June 2011.

28. Deshpande's (2013) important work on castelessness is also extremely relevant here, especially in underlining key differences between nationalist obviations of caste and post-Mandal recodings of such moves: 'Now, the claim to be casteless is itself a sign-it is instantly recognisable as the unmistakable mark of upper-caste identity, because the experience of apparent castelessness has been available only to the upper castes' (Deshpande 2010).

29. Outlook, 31 Oct. 2011. The police order encountered its own problems: 'policemen are finding it difficult to adhere to the DGP's "new name mantra" as they have become habitual using surnames like "Minhas sahib, Thakur sahib, Sharmaji and Khan sahib" while referring to their bosses or subordinates. They will now have to change their nameplates, badges that bear their names, that too at a time when the Centre is conducting a caste-based census' (The Tribune, 8 July 2011).

\section{ABSTRACTS}

This essay takes up social and political questions of naming that are often ignored in studies of inequality or exclusion. What if South Asian personal names ceased to reveal demographic 'data' about their bearers, scrambling any attempt at automatic categorization? The focus here is on naming and/or renaming for ideological reasons, and in such ways that the identity of the bearer is deliberately blurred. Grounded in ethnographic work amongst committed proponents of secularism in India (principally rationalist, humanist, and atheist activists), the essay identifies two main strategies that activists use for the production of 'disidentification': purification of the caste and religious connotations of names, and multiplication of those connotations in the giving of boundary-crossing names. Common to each is a rationale that seeks to break the association between name and pigeonholed identity. However, acts of renaming, and non-normative names as such, can be and are contested. Thus, in order to clarify what is at stake in the domain of secular naming practices the essay also focuses on debates and criticisms from both within and outside it.

\section{INDEX}

Keywords: names, India, South Asia, secularism, atheism, caste, activism, meta-names

\section{AUTHOR}

\section{JACOB COPEMAN}

School of Social and Political Science, University of Edinburgh 